\title{
Jejunum and Ileum Neuroendocrine Tumor cM0 TNM Finding v8
}

National Cancer Institute

\section{Source}

National Cancer Institute. Lejunum and Ileum Neuroendocrine Tumor cMO TNM Finding v8. NCI Thesaurus. Code C135096.

Jejunum and ileum neuroendocrine tumor without evidence of distant metastasis. (from AJCC 8th Ed.) 